\section{Vaping industry-funded academic scholarships}

\section{INTRODUCTION}

While the benefits versus the risks of increased e-cigarette use among adults remains unsettled, the fact that $21 \%$ of high school students in 2018 have used e-cigarettes in the last month is concerning to almost all policymakers and clinicians. ${ }^{1}$ A recent e-cigarette marketing technique involves the promotion of scholarships for students. Given the novelty of these promotions, we undertook an analysis to understand how widespread this practice is in the USA, along with characteristics of such scholarships.

\section{METHODS}

We conducted Web-based searches from June to August 2018 for publicly accessible documents related to scholarship opportunities by e-cigarette companies to youth or young adults. Words used to search for opportunities included combinations of 'vaping'/"e-cigarette'/"electronic cigarette'/"ENDS' and 'manufacturer'/ 'company'/'industry'/ trade association'/'distributor' and 'scholarship'/'university'/'college'/'education'/'essay'/'award'/'fellowship'. We omitted duplicate entities and secondary reports. We then extracted data from each website that described a scholarship opportunity related to e-cigarettes.

\section{RESULTS}

We discovered 21 entities that were offering 40 scholarships to youth and/or young adults (table 1). These scholarships originated from diverse segments within the vaping industry, including e-cigarette manufacturers, e-cigarette distributors, e-cigarette review websites and e-liquid manufacturers. Ranging from USD $\$ 300$ to $\$ 5000$, most of the highlighted scholarships required an essay submission, with most listing prompts related to e-cigarettes or eliciting information about the benefits of vaping. For instance, one scholarship allowed students to write an essay in response to the following prompt: 'What are the different types of e-cigarettes and what would you recommend?' and another asked applicants to discuss: 'Why do you think vaping is a safer alternative [to smoking cigarettes]? (online supplementary tables A and B)'. Furthermore, 11 out of the 21 entities expressed either

Table 1 Details of vaping scholarships*

\begin{tabular}{|c|c|c|c|c|c|c|c|}
\hline Name & Type of entity & $\begin{array}{l}\text { Age } \\
\text { restriction }\end{array}$ & Education level & $\begin{array}{l}\text { Essay topic related to } \\
\text { e-cigarettes }\end{array}$ & $\begin{array}{l}\text { Essay topic eliciting } \\
\text { vaping benefits }\end{array}$ & $\begin{array}{l}\text { Monetary prize } \\
\text { (\$) }\end{array}$ & $\begin{array}{l}\text { No of } \\
\text { awards }\end{array}$ \\
\hline Vape Craft & E-cigarette manufacturer & $18+$ & $\begin{array}{l}\text { Enrolled or Admitted to College or } \\
\text { University }\end{array}$ & No & No & $\$ 4000$ & 2 \\
\hline V2 & E-cigarette manufacturer & $18+$ & Admitted to College or University & Yes & Yes & $\begin{array}{l}\$ 3000 \\
\$ 2000 \\
\$ 1000\end{array}$ & 3 \\
\hline DaVinci Vaporizer & E-cigarette manufacturer & None & High School or College Student or Parent & Yes & Yes & $\$ 2500$ & 1 \\
\hline Mig Vapor & E-cigarette manufacturer & $18+$ & Enrolled in College or University & No & Yes & $\begin{array}{l}\$ 1000 \\
\$ 500 \\
\$ 500\end{array}$ & 3 \\
\hline MyKohu & E-cigarette manufacturer & None & $\begin{array}{l}\text { Enrolled or Admitted to College or } \\
\text { University }\end{array}$ & No & No & $\$ 1000$ & 3 \\
\hline Vaping Daily & E-cigarette review website & $18+$ & $\begin{array}{l}\text { Enrolled in College or } \\
\text { University }\end{array}$ & Yes & No & $\begin{array}{l}\$ 3000 \\
\$ 2000 \\
\$ 1000\end{array}$ & 3 \\
\hline SmokeTastic & E-cigarette review website & None & $\begin{array}{l}\text { Enrolled or Admitted to College or } \\
\text { University }\end{array}$ & Yes & No & $\$ 1000$ & 1 \\
\hline $\begin{array}{l}\text { ChurnMag (Anna } \\
\text { Hefrey) }\end{array}$ & E-cigarette review website & $18+$ & $\begin{array}{l}\text { Enrolled in College or } \\
\text { University }\end{array}$ & Yes & No & $\begin{array}{l}\$ 3500 \\
\$ 1500 \\
\$ 1000\end{array}$ & 3 \\
\hline Ecigarette Reviewed & E-cigarette review website & $14+$ & High School or College Student & Yes & No & $\begin{array}{l}\$ 3000 \\
\$ 1000 \\
\$ 1000\end{array}$ & 3 \\
\hline E Cigarette Pros & E-cigarette review website & None & High School or College Student & Yes & No & $\$ 2500$ & 1 \\
\hline ECASSOC.org & E-cigarette review website & None & High School or College Student & Yes & No & $\$ 500$ & 1 \\
\hline $\begin{array}{l}\text { Big D Vapor (quitday. } \\
\text { org) }\end{array}$ & E-cigarette distributor & $18+$ & $\mathrm{N} / \mathrm{A}$ & Yes & Yes & $\begin{array}{l}\$ 2000 \\
\$ 700 \\
\$ 300\end{array}$ & 3 \\
\hline Vaping Base & E-cigarette distributor & None & $\begin{array}{l}\text { Enrolled in College or } \\
\text { University }\end{array}$ & Yes & Yes & $\$ 1000$ & 1 \\
\hline VapeActive & E-cigarette distributor & $18+$ & $\begin{array}{l}\text { Enrolled in College or } \\
\text { University* }\end{array}$ & Yes & Yes & $\begin{array}{l}\$ 1000 \\
\$ 500\end{array}$ & 2 \\
\hline Breazy & E-cigarette distributor & $21+$ & Enrolled in Graduate Programme & No & No & $\$ 1000$ & 1 \\
\hline Vape Habitat & E-cigarette distributor & $18+$ & Enrolled in School & Yes & Yes & $\begin{array}{l}\$ 5000 \\
\$ 3000 \\
\$ 2000\end{array}$ & 3 \\
\hline Slick Vapes & E-cigarette distributor & $18+$ & $\begin{array}{l}\text { Enrolled in College or } \\
\text { University }\end{array}$ & Yes & Yes & $\$ 1000$ & 1 \\
\hline SmokShop & E-cigarette distributor & None & $\begin{array}{l}\text { Enrolled or Admitted to College or } \\
\text { University }\end{array}$ & Yes & No & $\$ 1000$ & 1 \\
\hline High Class Vape Co. & E-liquid manufacturer & None & High School or College Student & No & No & $\$ 4000$ & 2 \\
\hline Hot Juice & E-liquid manufacturer & $18+$ & Enrolled in College or University & No & No & $\$ 5000$ & 2 \\
\hline Thought Cloud & E-liquid manufacturer & $18+$ & Veterans Attending Community College & - & - & - & - \\
\hline
\end{tabular}

*At the time of this study's completion (1 August 2018), all scholarships were still being offered. However, since then, some of the scholarships have been suspended, are no longer active or do not have updated information available. 
interest or legal right to publish submissions on their websites (online supplementary table B). A substantial minority of the 40 scholarships either had no age restrictions or required only that the applicant be a high school student $(28 \%, \mathrm{n}=11)$. Parents of students were also encouraged to submit an essay in favour of vaping for one scholarship.

\section{DISCUSSION}

E-cigarette scholarships to youth and young adults are a concern for several reasons. These scholarships come at a dangerous time-when e-cigarette use by youth has become an epidemic. Policymakers around the USA are developing many approaches to decreasing youth e-cigarette use. Our research suggests that prohibitions on e-cigarette scholarships to youth are also needed, as many of these scholarships require youth under the age of 18 years (for whom use of e-cigarettes are illegal) to write positive essays about vaping. That the essay topics are not neutral introduces a strong positive bias for e-cigarettes, one that does not seem justified for youth given the known adverse health consequences. ${ }^{2}$

The scholarships are also likely designed to be a inexpensive way of increasing marketing and awareness of e-cigarette brands and devices, as they are listed not only on e-cigarette companies' websites but also on many university or college web sites for students on financial aid information pages. ${ }^{3}$ As these scholarships may also be used to obtain personally identifiable information for advertising, list building, retargeting, 'look-alike' digital marketing, and other purposes, colleges that list such scholarships should reexamine their inclusion.

The effects of industry-funded education, scholarship and sponsorship can be seen in a variety of industries. ${ }^{45}$ As regulation of e-cigarettes becomes a growing priority for the FDA and other state agencies, attention should be dedicated to the promotion of e-cigarette scholarships as a tactic that contributes to promoting youth e-cigarette use.

\section{Guido Baler, Karina Paci,}

\section{Sarah Dorothy Kowitt $\odot$, Adam 0 Goldstein}

University of North Carolina at Chapel Hill, Chapel Hill, North Carolina, USA

Correspondence to Dr Adam O Goldstein, University of North Carolina at Chapel Hill, Chapel Hill, North Carolina, USA; adam_goldstein@med.unc.edu

Contributors AOG was responsible for helping to create the original research questions and analysis plan. $G B$ wrote the first draft and conducted the analysis. KP and SDK contributed to the discussion and implications of the work. All authors contributed ideas, discussed the results and wrote the manuscript. All authors also approved the final version of the manuscript. AOG is the guarantor of the manuscript.

Funding The authors have not declared a specific grant for this research from any funding agency in the public, commercial or not-for-profit sectors.

Competing interests None declared.

Patient consent for publication Not required.

Provenance and peer review Not commissioned; externally peer reviewed. (c) Author(s) (or their employer(s)) 2020. No commercial re-use. See rights and permissions. Published by BMJ.

- Additional material is published online only. To view please visit the journal online (http://dx.doi.org/10. 1136/tobaccocontrol-2019-055158).

To cite Baler G, Paci K, Kowitt SD, et al. Tob Control 2020;29:e181-e182.

Received 15 May 2019

Revised 3 October 2019

Accepted 8 October 2019

Published Online First 26 December 2019

Tob Control 2020;29:e181-e182.

doi:10.1136/tobaccocontrol-2019-055158

\section{ORCID iD}

Sarah Dorothy Kowitt http://orcid.org/0000-00015216-3897

\section{REFERENCES}

1 Cullen KA, Ambrose BK, Gentzke AS, et al. Notes from the Field: Use of Electronic Cigarettes and Any Tobacco Product Among Middle and High School Students United States, 2011-2018. MMWR Morb Mortal Wkly Rep 2018:67:1276-7.

2 National Academies of Sciences, Engineering, Medicine. Public health consequences of e-cigarettes. Washington, DC: National Academies Press, 2018.

3 Binkley C. Vaping essays: e-cigarette sellers offering scholarships. secondary Vaping essays: e-cigarette sellers offering scholarships, 2018. https://apnews.com/ a35ba8a0200c4a27943da3b9254b9fe5

4 O'Brien KS, Lynott D, Miller PG. Alcohol industry sponsorship and alcohol-related harms in Australian university sportspeople/athletes. Drug Alcohol Rev 2013:32:241-7.

5 DeJong C, Aguilar T, Tseng C-W, et al. Pharmaceutical industry-sponsored meals and physician prescribing patterns for Medicare beneficiaries. JAMA Intern Med 2016;176:1114-22. 